\title{
HPT Türevi UV Absorblayıcıların PET İplik ve Kumaşların UV Dayanımı Üzerine Etkilerinin İncelenmesi
}

\author{
Serpil Koral Koç ${ }^{1 *}$, Nimet Doğmuş Yılmaz \\ ${ }^{1}$ Bursa Uludağ Üniversitesi, Mühendislik Fakültesi, Tekstil Mühendisliği Bölümü, Bursa, Türkiye (ORCID: 0000-0002-0739-8256) \\ ${ }^{2}$ Bursa Uludağ Üniversitesi, Mühendislik Fakültesi, Tekstil Mühendisliği Bölümü, Bursa, Türkiye (ORCID: 0000-0002-7774-8856)
}

(International Symposium on Multidisciplinary Studies and Innovative Technologies (ISMSIT) 2020 - 22-24 October 2020)

(DOI: 10.31590/ejosat.821635)

ATIF/REFERENCE: Koral Koç, S. \& Doğmuş Yılmaz, N. (2020). HPT Türevi UV Absorblayıcıların PET İplik ve Kumaşların UV Dayanımı Üzerine Etkilerinin İncelenmesi. Avrupa Bilim ve Teknoloji Dergisi, (Özel Sayı), 276-282.

$\ddot{O} \mathbf{z}$

Morötesi (ultraviyole, UV) ışımanın tüm polimerler gibi tekstil malzemelerinin performansları üzerinde de olumsuz etkileri bulunmaktadır. Bu etkiler, dış ortam uygulamaları için üretilmiş ürünlerde daha da önem kazanmaktadır. UV ışımanın olumsuz etkisini azaltarak ürünlerin daha uzun süre kullanımını sağlayabilmek amacıyla UV absorblayıcı katkı maddeleri kullanılmaktadır. Bu katk1 maddeleri masterbatch yöntemiyle, üretim sırasında lif yapısına katılarak tekstil ürünlerinin UV dirençleri arttırılabilinir. Polimerlerin açık hava koşullarındaki performanslarını belirleyebilmek amacıyla yapılan testlere dış ortam şartlandırma testleri denilmektedir. Bu testler, gerçek dış ortam şartlarında yapılabileceği gibi laboratuvar koşullarında dış ortam şartlarını simüle eden cihazlarında da gerçekleştirilebilinir. Laboratuvar ortamında yapılan testler hızlandırılımış yapay dış ortam şartlandırma testleri olarak adlandırılır. Açık hava uygulamarı için poliakrilonitril liflerinden yapılmış tekstil ürünleri yaygın olarak kullanılmaktadır. Ancak bu liflerin tedariklerinde çeşitli zorluklarla karşılaşılması ve maliyetlerinin yüksek olması bu tür uygulamalar için polietilen tereftalat (PET) liflerine olan ilgiyi arttırmaktadır. Bu çalışmada hızlandırılmış yapay dış ortam şartlandırma testleri, katkısız PET (referans PET) ve hidroksifenil triazin (HPT) türevi ticari bir katkı malzemesi olan Tinuvin 1577 ED ile UV 1şımaya karşı direnci arttırılmış PET (katkılı PET) iplik ve bu iplikler kullanılarak dokunmuş kumaşlara 1000 saat süre ile uygulanmıştır. Her 250 saatte bir numunelerin kopma mukavemeti, kopma uzaması ve renk değişimi özellikleri kayıt edilmiştir. Şartlandırma testlerinden önce yapılan çekme deneyleri katkı maddelerinin PET ipliklerin kopma mukavemetlerini azaltıp, kopma uzaması değerlerini arttırdığını, dolayısı ile mekanik özellikler üzerinde olumsuz bir etkisinin olduğunu göstermiştir. Ancak 1000 saatlik dış ortam şartlandırma testlerinin sonunda bu katkı maddelerinin UV ışımanın PET iplik ve kumaşların mekanik özellik ve renk değiş̧imi üzerindeki olumsuz etkisini belirgin bir oranda azalttığı tespit edilmiştir.

Anahtar Kelimeler: Dış ortam şartlandırma testleri, UV dayanımı arttırılmış PET lifleri, UV ışıma, UV absorblayıcı, Hidroksifenil triazin

\section{Effects of HPT Derivative UV Absorbers on the UV Resistance of PET Yarns and Fabrics}

\begin{abstract}
Ultraviolet (UV) radiation has negative effects on the performance of textile materials like all the polymers. These effects become more critical in products produced for outdoor applications. UV absorbers can be used to reduce the negative effects of UV radiation and ensure the usage of products for a longer time. By adding these chemicals to textile fibers during production by the masterbatch method, their UV resistance can be improved. The tests performed to determine the performance of polymers in outdoor applications are called outdoor weathering tests. Weathering tests can be performed under real outdoor conditions or in laboratories on de vices that simulate these conditions. Tests performed in the laboratory environment are called accelerated artificial weathering tests. Textile products produced from polyacrylonitrile fibers are commonly used for outdoor applications. However, difficulties in their supplies and their high costs increase the interest in polyethylene terephthalate (PET) fibers for such applications. In this study, standard
\end{abstract}

\footnotetext{
* Sorumlu Yazar: Bursa Uludağ Üniversitesi, Mühendislik Fakültesi, Tekstil Mühendisliği Bölümü, Bursa, Türkiye, ORCID: 0000-0002-0739-8256, skoral@,uludag.edu.tr
} 
(reference) and UV resistant PET were subjected to accelerated artificial outdoor weathering tests for 1000 hours. The UV resistant PET fibers were produced by the addition of an (HPT) derivative, Tinuvin 1577 ED. The samples were used in yarn and fabric form. Tensile strength, elongation at break, and color change of the samples were recorded every 250 hours. Tensile tests carried out before the weathering tests showed that additives reduced the tensile strength of PET yarns and fabrics and increased their breaking elongations. They have negative effects on the mechanical properties. However, at the end of 1000 hours, it was observed that these additives significantly hindered the negative effect of UV radiation on the mechanical properties and color change of PET yarns and fabrics.

Keywords: Outdoor weathering tests, UV resistant PET fibers, UV radiation, UV absorber, Hydroxyphenyl triazine.

\section{Giriş}

Güneş 1şınlarından kaynaklanan morötesi (ultraviyole, UV) 1şıma, dış ortam kullanımı olan, endüstriyel ve günlük kullanım amacı taşıyan birçok ürün üzerinde olumsuz etkilere sahiptir. Gün ışığının olumsuz etkileri, sıcaklık, nem gibi diğer açık hava bileşenleri ile bir araya geldiğinde, polimerlerin kimyasal ve mekanik özellikleri üzerinde geri dönüşü olmayan etkiler yaratır. Polimerik malzeme olan tekstil materyalleri de tüm polimerler gibi UV ışımadan olumsuz yönde etkilenmektedir. Bu etki, özellikle sürekli gün 1şı̆̆ına maruz kaldıkları bahçe, restaurant, otel gibi dış mekan uygulamalarında daha da önem kazanmaktadır.

Polimerleri UV ışımanın zararlı etkilerinden korumak ve degradasyonlarını önlemek için UV absorblayıcı katkı maddeleri kullanılmaktadır. UV absorblayıcılar genel olarak UV absorblayıcı (UVA) ve engellenmiş amin 1şık stabilizatörleri (Hindered Amin Light Stabilizer, HALS) olmak üzere iki grupta sınıflandırılabilmektedir. (Anonim 2012).

UVA malzemeler, fotokimyasal reaksiyon başlamadan UV ışımayı absorbe ederek radikal oluşum oranının düşürülmesinde etkin bir işlev görür. Ana etkinlik mekanizmaları, zararlı UV 1şımayı absorbe etme ve çok daha az zararlı olan 1sı enerjisine dönüştürme esasına dayanır. UVA malzemelerin performansları, absorbe edilen UV 1şıma miktarı ve UV 1şımaya maruz kalan numunenin kalınlığı ile doğrudan ilişkilidir. Bu nedenle UVA malzemelerin çalışma prensipleri Lambert-Beer yasası ile açıklanır ve bu durum UVA'ların en önemli dezavantajıdır (Gugumus 2002). Tekstil liflerinin ince yapılı malzemeler olmalarına rağmen farklı yapıdaki UVA malzemelerin çeşitli formülasyon çalışmaları ile pek çok tekstil lifinin UV 1şımaya karşı direncini artttrımak mümkün olmaktadir.

Işık stabilizatörü olarak işlev gören ikinci ana kimyasal grubu HALS yapılardır. HALS grubu kimyasal ürünler, 2,2,6,6-tetrametil piperidin türevi yapılardır ve bir çok polimerin UV 1şımaya karşı stabilitesinin sağlanmasında etkin bir mekanizmaya sahiptir (Anonim 2012). Bu yapılar; çözülebilirler, migrasyon dayanımları iyidir, molekül ağırlıklarına ve piperidin halkaları arasındaki bağ kuvvetine bağlı olmak kaydıyla yüksek termal stabilite gösterirler (Schaller 2009). HALS grubu kimyasal katkılar UV 1şıma absorbsiyonu gerçekleştirmez. Bu tür katkılar direkt olarak polimer degredasyonunu önlemeye yönelik işlev görmektedir. Fotokimyasal olarak başlayan degredasyon reaksiyonlarını yavaşlatma özelliklerine sahiptirler (McCusker 1999a). UVA ile karşılaştırıldığında, HALS'in bir diğer avantajı belirli bir seviyede katkı konsantrasyonu ve ışımaya maruz kalan numunenin belirli bir kalınlığa gereksinim duymuyor olmasıdır. HALS ile nispeten düşük konsantrasyonlarda oldukça önemli stabilizasyon dereceleri elde edilebilmektedir. HALS'ın yüksek performans sağlaması ve uzun ömürlü olması, stabilizasyon prosesi boyunca tüketilmek yerine yenilenebildikleri bir döngüde aktivite gösteriyor olmalarından kaynaklanmaktadır (McCusker 1999b).

Dış ortam kullanımına uygun döşemelik kumaş, bahçe mobilyası kumaşı, bahçe şemsiyesi kumaşı, tentelik kumaşlar gibi ürünlerde akrilik ipliklerin yaygın olarak kullanıldığı görülmektedir. Ancak bu ipliklerin üretim ve tedariğinde yaşanan kısıtlamalar ve fiyatlarının yüksek oluşu polietilen tereftalat (PET), iplikleri bu tür ürünler için iyi bir alternatif haline gelmektedir. PET lifleri de diğer tekstil lifleri gibi uzun süre güneş 1şımasına maruz kaldığı zaman olumsuz yönde etkilenmektedir. Bu olumsuzlukları azaltmak amacıyla çeşitli kimyasal katkı maddelerinin lif üretimi sırasında yapılarına ilave edilmesiyle UV ışınlarına karşı dayanımı arttırılmış PET lifleri elde edilebilmektedir.

D1ş ortam uygulamalarında kullanılmak üzere geliştirilen ürünlerin performans ölçümleri büyük önem taşır. D1ş ortam şartlandırma testleri bu amaçla kullanılır. Dış ortam şartlandırma testleri, belirli iklim koşullarına karşı malzemenin vereceği tepkiyi ve buna bağlı olarak ürün performansının değerlendirilmesi için yürütülen çalışmalardır. Bu testler, gerçek diş ortam şartlarında (gerçek dış ortam şartlandırma testleri) yapılabileceği gibi laboratuvarda bu amaç için üretilmiş cihazlar kullanılarak da (hızlandırılmış yapay dış ortam şartlandırma testleri) gerçekleştirilebilir.

Gerçek dış ortam şartlandırma testleri, kendi içinde direkt/doğal dış ortam şartlandırması ve hızlandırılmış doğal dış ortam şartlandırması olarak iki gruba ayrılmaktadır. Bu testlerdeki temel prensip, spesifik bir iklimde, nihai kullanıma uygun olarak, performans beklentisine göre belirlenmiş bir süre boyunca malzemeyi doğal hava şartları altında, açık alanda bekletmektir. Bunun için özel numune tutucu sistemler, ya da numune yerleştirme standları kullanılmaktadır (Şekil 1(a)). Numunenin çeşidi doğrultusunda farklı test standartları izlenebilir.

Hızlandırılmış doğal dış ortam şartlandırma testlerinde hedeflenen, doğal dış ortam testlerinin temel etken faktörlerinin (ışıma, sıcaklık, nem) şiddetinin arttırılarak numunelerin daha kısa sürede degredasyona uğramasını sağlamaktır. Bu testler temel olarak "Equatorial Mount with Mirrors for Acceleration (EMMA)" ve "Equatorial Mount with Mirrors for Acceleration with Water (EMMAQUA)" denilen iki ayrı cihaz ile gerçekleştirilmektedir. Ancak özel uygulamalar için farklı test methodları da bulunmaktadır (Wypych 2013). EMMA test düzeneği, ayna yardımıyla performans beklenen test standardına göre ihtiyaç duyulan hızlandırmayı 
sağlayan bir düzenektir. EMMAQUA'nın farkı ise, spreyleme ya da yağmurlama olarak tanımlanan iklimsel döngüleri de test periyoduna ekleyebiliyor olmasıdır (Şekil 1(b)).

Hızlandırılmış yapay dış ortam şartlandırma testleri güneș ışımasını simüle eden lambaların kullanıldığı cihazlarda gerçekleștirilir (Sekil 1 (c)). Floresan lambalı, karbon ark lambalı, metal halid lambalı cihazların da yaygın olarak kullanılmasına rağmen performans etkileri ve uygun filtreleme sistemleri ile gün ışı̆̆ına en yakın simülasyonu sağlaması nedeniyle ksenon ark lambalı cihazlar daha çok tercih edilmektedir. Ksenon lamba, doğru filtrelendiği zaman, doğal UV ve görünür ışı̆̆ı en iyi simüle eden yapay ışık kaynağıdır. Ksenon ark, kapalı kuvars tüpün içinde yer alan ve gaz akışına duyarlı bir lambadır. Bu ışık kaynağı entegreli cihazlar polimer, plastik, tekstil, boya ve otomotiv endüstrileri için gerçekleştirilen testlerde yaygın olarak kullanılır (Anonim 2015). Şartlandırma cihazının tasarımına bağlı olarak test numuneleri kabin içerisinde yatay ya da dikey olarak yerleştirilebilmektedir. İki ya da üç katlı, hareketli, döner numune yerleştirme mekanizmasına sahip yüksek numune kapasiteli cihazlarda, lambanın kabin ortasında konumlanmış olması nedeniyle tüm numunelerin yüzeyine eşit miktarda ışıma ulaşmaktadır.
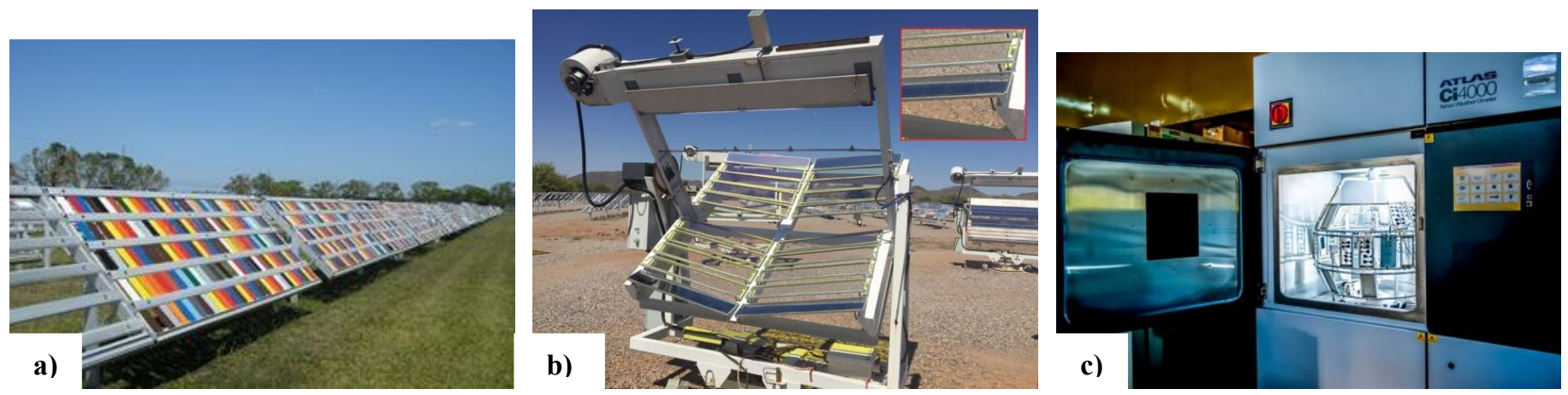

Şekil 1.(a) Gerçek dlş ortam şartlandırmasına bırakılmış numune örnekleri, (b) EMMA/ EMMQUA test düzeneği,

(c) Hızlandırılmış yapay dı̧̧ ortam şartlandırma test cihazı

Malzeme dayanımı açısından, hızlandırılmış yapay dış ortam şartlandırma testlerine ait sonuçların, dış ortamda yürütülmüş testlerin sonuçlarıyla ne derece örtüştügünün anlaşılabilmesi oldukça önemlidir. Spektrumun dışında kalan kısa dalga boylu 1şımalar, Sürekli ışığa maruz kalma, özellikle yapay ışık kaynakları ile aşırı ve yüksek seviyeli ışımaya maruz kalma, yüksek numune sıcaklıkları, açık ve koyu renkli malzemeler arasındaki aşırı sıcaklık farkı, sıcaklık döngüsünün olmaması, doğal olmayan oranlarda nem varlı̆̆ı, kirlilik ve diğer biyolojik organizmaların varlığı gerçek dış ortam şartlandırma testleri ve hızlandırılmış yapay şartlandırma testleri arasında tam bir korelasyon olmamasının nedenlerinden bazılarıdır. (Anonim 2015). Yine yapay şartlandırma testleri hızlı sonuç vermesi ve laboratuvar koşullarında gerçekleştirilebilmeleri nedeniyle sanayide yaygın bir şekilde kullanılmaktadır.

$\mathrm{Bu}$ çalışmada HPT türevi bir UV absorblayıcı madde kullanılarak UV ışımaya karşı dayanıklılığı arttırılmış PET iplik ve kumaşların hızlandırılmış yapay dış ortam şartlandırma testleri sonrasında mekanik özellik ve renklerinde meydana gelen değişimler incelenmiş̧ir. Şartlandırma testleri 1000 saat gibi nispeten uzun bir süre ile gerçekleştirilmiştir. Elde edilen sonuçlar standart PET iplik ve kumaşların özellikleri ile karşılaştırılarak kullanılan katkı maddesinin PET tekstil mamulerinin UV ışımaya karşı direncini arttırmadaki etkisi incelenmiştir.

\section{Materyal ve Metot}

\subsection{Materyal}

$\mathrm{Bu}$ çalışmada numuneler iplik ve kumaş formunda kullanılmıştır.

Çalışmada katkısız PET (referans iplik) ve UV ışımaya karşı dayanımı arttırılmış PET (katkılı iplik) olmak üzere iki çeşit iplik kullanılmıştır. Katkılı PET, \%1,2 oranında, HPT türevi ticari bir katkı malzemesi olan Tinuvin 1577 ED katkısı ile üretilmiştir. Tinuvin 1577 ED; düşük uçuculuk göstermesi, ince polimerik malzemelerin dış ortam şartlandırma performanslarını iyileştirmesi ve nispeten modern HPT grubunda sayılması nedeniyle yaygın olarak PET ipliklerin UV dayanımın iyileştirmede tercih edilmektedir.

Her iki iplik grubu da yalancı büküm yöntemi ile tekstüre edilmiş formda, 96 filamentli, 300 denye ve ekru renktedir. İplikler ticari olarak temin edilmiştir.

Kumaş numuneleri referans ve katkılı PET ipliklerden, atkı sıklı̆̆ 16 atk1/cm ve çözgü sıklığı 30 çözgü/cm olacak şekilde bezayağı örgü yapısında üretilmiştir. Kumaşlar dokunurken atkı ve çözgü ipliği olarak aynı cins iplik kullanılmıştır. Kumaşların üretimi, numune ölçekli CCI Tech Inc. marka dokuma makinesinde gerçekleştirilmiştir. Kumaşlar dokumadan sonra $40^{\circ} \mathrm{C}$ 'de ev tipi yıkama işlemine tabi tutulmuş ve en-boy sabitlemesi için $160^{\circ} \mathrm{C}$ 'de $5 \mathrm{~m} / \mathrm{dak}$ hız ile ramdan geçirilmiştir. 


\subsection{Metot}

\subsubsection{Hızlandırılmış Yapay Dış Ortam Şartlandırma Testleri}

Hızlandırılmış yapay dış ortam şartlandırma testleri, “TS 4460 EN ISO 105-B04 Yapay Hava Şartlarına Karş1 Renk Haslığ1 Ksenon Lamba ile Soldurma Deneyi" standardına göre Atlas marka Ci 3000+ Weather-Ometer cihazında gerçekleştirilmiştir. Kullanılan standart ile ilgili bilgi Tablo 1'de verilmiştir.

Tablo 1. TS 4460 EN ISO 105-B04 standard test parametreleri

\begin{tabular}{|c|c|c|}
\hline \multicolumn{2}{|l|}{ Filtre Sistemi } & $380-750 \mathrm{~nm}$ arasında $\% 90$ 1şık geçirgenliğinde \\
\hline \multicolumn{2}{|l|}{ Lamba Türü } & Xenon \\
\hline \multirow{3}{*}{ Işııma } & $300-400 \mathrm{~nm}$ & $42 \pm 2 \mathrm{~W} / \mathrm{m}^{2}$ \\
\hline & $340 \mathrm{~nm}$ & $0.35 \pm 0.01 \mathrm{~W} /\left(\mathrm{m}^{2} \mathrm{~nm}\right)$ \\
\hline & $420 \mathrm{~nm}$ & - \\
\hline \multirow{3}{*}{ Referans Sicaklık } & Kabin Sıcaklığ 1 & Max. $40^{\circ} \mathrm{C}$ \\
\hline & Siyah Panel Sicaklığı & Max. $60^{\circ} \mathrm{C}$ \\
\hline & Siyah Standart Sicaklı̆g 1 & - \\
\hline \multicolumn{2}{|c|}{ Su Spreyleme Döngüsü } & 29 dakika kuru, 1 dakika ıslak döngü, sürekli ışıma \\
\hline
\end{tabular}

İplik ve kumaş numuneleri PVC kaplanmış karton kartela üzerine sabitlenerek cihazın numune tutucu aparatlarına uygun halde hazırlanmıştır (Şekil 2). Karton kartelanın PVC ile kaplanmasının nedeni, dış ortam şartlandırma testi süresince, yağmurlama ve kabin içi yüksek nem oranından kartelanın numunelerin cihaz içindeki konumlarının değiştirmesini önlemektir.

Dış ortam şartlandırma testi 1000 saat süre ile gerçekleştirilmiş olup, sıfırıncı saatten başlamak kaydıyla her 250 saatte bir referans ve katkılı iplik ve kumaş numunelerindeki kopma mukavemeti, kopma uzaması ve renk değişimleri ölçülmüştür.



Şekil 2. Çalışmada kullanılan numunelerin numune tutucu üzerindeki yerleşim; a) İlik numuneleri, b) Kumaş numuneleri

\subsection{2. Çekme Deneyleri}

Çekme deneyleri Textechno Statimat Me+ test cihazında gerçekleştirilmiştir. Dış ortam şartlandırma testlerinin yapıldığı Atlas Ci 3000+ Weather-Ometer cihazına numuneler standart ve belirli ölçüleri olan numune tutucular arasına yerleştirilmiştir (Şekil 2). Bu nedenle numune boyutları herhangi bir çekme testi standardına göre ayarlanamamışıı. Numuneler, şartlandırma test cihazının numune tutucularının olanak verdiği uzunlukta kullanılmak zorunda kalınmışıtır. Çekme test cihazının hızı ise numuneler 20 saniye içinde kopacak şekilde optimize edilmiştir. Çalışmada kullanılan çekme deneyi parametreleri Tablo 2'de verilmiştir. Yük taşıma 
kapasitesi çözgü yönünde daha fazla olduğu için dış ortam şartlandırılmasına maruz bırakılmış kumaş numuneleri için çekme deneyleri sadece çözgü yönünden alınan numuneler için gerçekleştirilmiştir.

İplik ve kumaş numunelerinin kopma mukavemetleri ve kopma uzamaları her 250 saatte bir ölçülmüştür. Sıfirıncı saat değerlerine oranla, her 250 saatte bir alınan ölçüm sonuçlarının numune üzerinde yarattığı \% kopma mukavemeti ve kopma uzaması değişimleri hesaplanmıştır.

Tablo 2. Çekme Deneylerinde Kullanılan Test Parametreleri

\begin{tabular}{l|c|c}
\hline Parametre & İplik Parametreleri & Kumaş Parametreleri \\
\hline Numune Genişliği $(\mathrm{mm})$ & - & 20 \\
\hline Çeneler Arası Mesafe $(\mathrm{mm})$ & 100 & 100 \\
\hline Ön Gerilim $(\mathrm{N})$ & 2 & 2 \\
\hline Çene Hareket Hızı $(\mathrm{mm} / \mathrm{dk})$ & 100 & 100 \\
\hline
\end{tabular}

\subsubsection{Renk Değişimi Ölçümü}

Referans ve katkılı kumaş numunelerindeki sararma Datacolor Spektraflash SF600X cihazında yapılan renk ölçümleri ile belirlenmiştir. Ölçümler her 250 saatte bir şartlandırma kabininden çıkartılan numunelere uygulanmıştır.

\section{Araştırma Sonuçları ve Tartışma}

Hızlandırılmış yapay dış ortam şartlandırma testlerinin etkisi ile iplik ve kumaş numunelerinde meydana gelen değişim her 250 saatte bir çekme testleri ve renk değişimi ölçümleri ile incelenmiş ve sonuçlar numunelerin işlem öncesindeki durumları ile karşılaştırılmıştır. Çekme testlerinin sonuçları Tablo 3,4 ve Şekil 3,4'te verilmiştir.

Şartlandırma öncesinde referans ipliklerin katkılı ipliklere göre daha yüksek kopma mukavemeti ve daha düşük kopma uzaması değerlerine sahip olduğu görülmektedir. Katkı maddeleri polimer yapısının saflığını bozarak mekanik özelliklerini olumsuz yönde etkileyebilir. Burada da benzer bir durum gözlenmiştir. Üretim sırasında PET liflerinin yapısına bu liflerin UV 1şımaya karşı dayanıklılıklarını arttırmak amacıyla ilave edilen HPT türevi kimyasal malzemeler kopma mukavemetinde düşüşe, kopma uzamasında ise bir artışa sebep olmuştur (Tablo 3).

İlk 250 saatlik şartlandırma testlerinin sonuna yapılan çekme deneyleri referans ipliklerin katkılı ipliklere göre belirgin oranda mukavemet kaybına uğradığını göstermiştir. Referans iplikler, kopma mukavemeti değerlerinin yaklaşı \%45'ini kaybederken bu kayıp katkılı ipliklerde sadece \%22 olmuştur. Benzer durum kopma uzamasında da gözlenmiştir. Referans ipliğin kopma uzaması $\% 58$ oranında azalırken, katkılı ipliğin kopma uzaması \%46 oranında azalmıştır. Değerlerdeki bu düşüş 1000 saatin sonuna kadar devam etmiş ve 1000 saat sonunda referans ipliğin kopma mukavemeti \%79, kopma uzaması ise $\% 90$ oranında azalmıştır. Bu durum, katkılı ipliklerde kopma mukavemetinde $\% 42$ ve kopma uzamasında \%65'lik bir azalma olarak gözlenmiş̧ir. Sonuçlar UV ışımanın, PET ipliklerinin uzama davranışları üzerinde, kopma mukavemetlerine oranla daha etkili olduğunu göstermektedir. Ayrıca UV ı̧̧ımaya karşı dayanıklılık kazandırması beklenen HPT türevi katkı maddelerinin etkili olduğu ve PET ipliklerin kopma mukavemeti ve kopma uzaması değerlerindeki kayıpları belirgin bir şekilde engelledikleri görülmüştür (Şekil 3).

Tablo 3. İplik Numunelerine Uygulanan Çekme Deneylerinin Sonuçları

\begin{tabular}{|c|c|c|c|c|c|}
\hline Ölçüm Süresi (Saat) & Numune & Kopma Mukavemeti (cN/dtex) & Kayıр (\%) & Kopma Uzaması (\%) & Kayıр (\%) \\
\hline \multirow{2}{*}{0} & Referans & 3,57 & - & 24,24 & - \\
\hline & Katk1l1 & 3,45 & - & 26,18 & - \\
\hline \multirow{2}{*}{250} & Referans & 1,88 & 45,63 & 10,01 & 58,70 \\
\hline & Katkıl1 & 2,67 & 22,60 & 13,93 & 46,79 \\
\hline \multirow{2}{*}{500} & Referans & 1,2 & 66,38 & 5,51 & 77,26 \\
\hline & Katk1l1 & 2,28 & 33,91 & 10,89 & 58,40 \\
\hline \multirow{2}{*}{750} & Referans & 1,06 & 70,30 & 3,71 & 84,69 \\
\hline & Katk1l1 & 2,12 & 38,55 & 10,15 & 61,22 \\
\hline \multirow{2}{*}{1000} & Referans & 0,74 & 79,27 & 2,34 & 90,35 \\
\hline & Katk1l1 & 2,0 & 42,02 & 9,07 & 65,35 \\
\hline
\end{tabular}


European Journal of Science and Technology
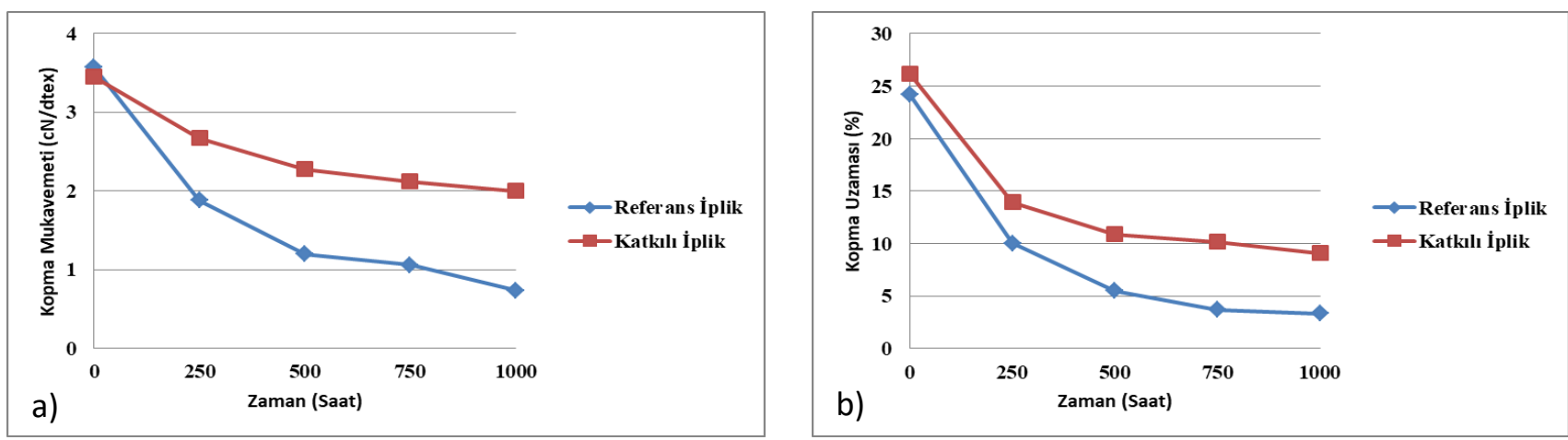

Şekil 3. İplik Numunelerinin Mekanik Özelliklerinin Hızlandırılmış Yapay Dış Ortam Şartlandırma Test Süresine Bağlı Olarak Değişimi; a)Kopma Mukavemeti, b)Kopma Uzaması

Kumaş numunelerinin çekme deney sonuçları incelendiğinde iplik numunelerine benzer durumun söz konusu olduğu görülmüştür. Şartlandırma testlerinden önce katkılı kumaş, referans kumaşa göre daha düşük kopma kuvveti ve daha yüksek kopma uzaması değerleri vermiştir (Tablo 4). Buna ilave olarak yine iplik numunelerinde olduğu gibi, en büyük mekanik kayıplar ilk 250 saatte görülmüştür. Numuneler başlangıç kopma yüklerinin ve kopma uzamalarının yaklaşık \%70'ini ilk 250 saatte kaybetmiştir. Bu süre zarfında katkılı PET ipliklerden üretilen kumaşlar sadece \%38 civarında bir kopma yükü ve yaklaşık \%53 oranında bir kopma uzaması kaybına uğramıştır (Şekil 4). Daha sonra kayıp hızı azalmış ancak değerlerdeki düşüş devam etmiştir. 1000 saat sonunda referans kumaşların kopma kuvveti değerlerinde \%86, katkılı numunelerin kopma kuvvetlerinde ise \%70 oranında bir azalma tespit edilmiştir. Kopma uzaması değerlerinde ise test sonunda referans kumaşta yaklaşı \% $\% 86$, katkılı kumaşta ise yaklaşık \%71'lik bir kayıp meydana gelmiştir. Çekme deneylerinin sonuçları, katkı maddelerinin PET iplik ve kumaş numunelerinin mekanik özelliklerindeki kayıpları belirgin bir şekilde önlediğini göstermektedir.

\section{Tablo 4. Kumaş Numunelerine Uygulanan Çekme Deneylerinin Sonuçları}

\begin{tabular}{|c|c|c|c|c|c|}
\hline Ölçüm Süresi (Saat) & Numune & Kopma Kuvveti (N) & Кауıр (\%) & Kopma Uzaması (\%) & Kayıp (\%) \\
\hline \multirow{2}{*}{0} & Referans & 525,77 & - & 31,13 & - \\
\hline & Katkı11 & 505,96 & - & 33,98 & - \\
\hline \multirow{2}{*}{250} & Referans & 161,04 & 69,37 & 8,99 & 71,12 \\
\hline & Katk1l1 & 312,76 & 38,18 & 16,13 & 52,53 \\
\hline \multirow{2}{*}{500} & Referans & 100,01 & 80,97 & 4,99 & 83,97 \\
\hline & Katk111 & 209,27 & 58,63 & 11,47 & 66,24 \\
\hline \multirow{2}{*}{750} & Referans & 73,27 & 86,06 & 3,70 & 88,11 \\
\hline & Katk1lı & 170,79 & 66,24 & 8,86 & 73,92 \\
\hline \multirow{2}{*}{1000} & Referans & 71,12 & 86,47 & 3,29 & 89,43 \\
\hline & Katkı11 & 147,75 & 70,79 & 6,72 & 80,22 \\
\hline
\end{tabular}
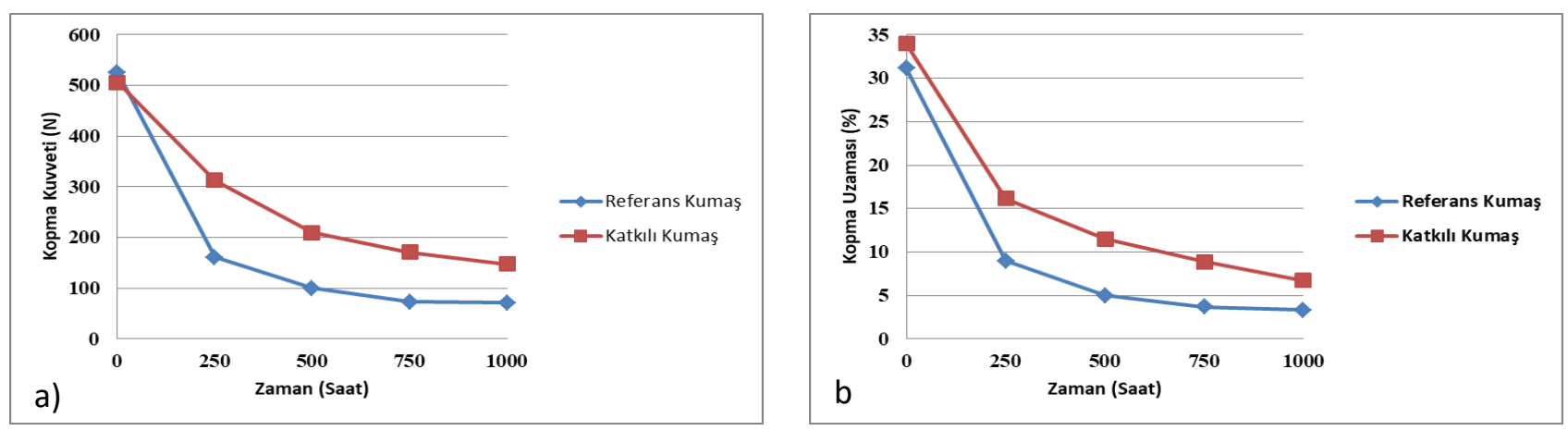

Şekil 4. Kumaş Numunelerinin Mekanik Özelliklerinin Hızlandırılmış Yapay Dış Ortam Şartlandırma Test Süresine Bağlı Olarak Değişimi; a)Kopma Mukavemeti, b)Kopma Uzaması

Şartlandırma kabininden çıkarılan numunelerin her 250 saatte bir spektrofotometre yardımı ile renk ölçümleri gerçekleştirilmiştir. Fotodegredasyonun etkisi, polimerik tekstil malzemelerinde özellikle parlaklık kaybı ve sararma olarak kendini gösterdiği ve numuneler ekru (ham, boyasız) renkte olduğu için, renk ölçümü sonrası b değerindeki değişim dikkate alınmıştır. Ölçüm sonuçları Tablo 5 'te verilmiştir. $\Delta \mathrm{b}$ değeri, numunenin sarılık değerindeki değişimi ifade ederken, $\Delta \mathrm{E}$ değeri renk değişimindeki toplam farkı ifade etmektedir.

Referans kumaş numunelerinin $\Delta \mathrm{b}$ değerlerinde 1000 saatin sonuna kadar kademeli olarak artış görülmüştür. En büyük değişim 250 'nci saatten 500'üncü saate geçerken gözlemlenmiştir. Katkılı kumaş numunelerinin renk ölçümlerinde ise varyasyon gözlenmiştir. Dış ortam şartlandırma testleri uzun zaman alan ve yüksek maliyetli testlerdir. Ayrıca cihaz kabininde belirli sayıda e-ISSN: 2148-2683 
numune yerleştirilmesi için yer bulunmaktadır. Bu kısıtlamalar nedeniyle testler çok tekrarlı yapılamamıştır. Bu nedenle varyasyonun kaynağını tam olarak belirlemek mümkün olamamıştır. Ancak referans kumaş numuneleri ile karşılaştırma yapıldığında, 1000 saat sonunda, katkılı kumaş numunelerinin neredeyse \%25 daha az sararma gösterdiği tespit edilmiştir.

Referans ve katkılı kumaş numunelerinin 1000 saat şartlandırma boyunca toplam renk değişimleri incelendiğinde, referans kumaş numunelerinin renklerinin başlangıç renklerine göre yaklaşık iki kat bir değişime uğradığı gözlenmiş̧ir. Katkılı kumaş numunelerinin ise kısmen renklerini koruduğu, sadece \%30 civarında bir renk değişimine uğradığı tespit edilmiştir. Bu da kullanılan katkı malzemesinin kopma kuvveti ve kopma uzaması değerlerindeki kaybı önleyici etkisinin yanısıra renk değişimi üzerinde de pozitif etkisinin olduğunu ortaya koymuştur.

Tablo 5. Renk Değişimi Ölçümlerinin Sonuçları

\begin{tabular}{l|c|c|c|c}
\hline \multirow{2}{*}{ ölçüm Süresi (Saat) } & \multicolumn{2}{|c|}{ Referans Kumaş } & \multicolumn{2}{c}{ Katkll Kumaş } \\
\cline { 2 - 4 } & $\Delta \mathbf{b}$ & $\Delta \mathbf{E}$ & $\Delta \mathbf{b}$ & $\Delta \mathbf{E}$ \\
\hline 250 & 2,39 & 2,79 & 2,32 & 2,37 \\
\hline 500 & 3,33 & 4,74 & 2,09 & 2,21 \\
\hline 750 & 3,94 & 6,38 & 3,27 & 4,02 \\
\hline 1000 & 4,08 & 6,72 & 3,01 & 3,57 \\
\hline
\end{tabular}

\section{Sonuç}

$\mathrm{Bu}$ çalışmanın amacı, PET tekstil ürünlerine dış ortam şartlarına karşı dayanım kazandırması beklenen HPT bazlı UV absorblayıcı katk1 maddesi Tinuvin 1577 ED’nin, bu malzemelere performans avantajı sağlayıp sağlamadığının tespit edilmesidir. Bu amaçla katkısız (referans) ve UV direnci arttırılmış (katkılı) PET iplik ve kumaş numuneleri gerçek dış ortam şartlarını simüle eden hızlandırılmış yapay dış ortam şartlandırma testlerine 1000 saat süre ile tabii tutulmuştur.

Şartlandırma testleri öncesinde numunelere yapılan çekme deneyleri, katkı maddelerinin PET iplik ve kumaşların kopma mukavemetlerinde azalmaya, kopma uzamalarında ise artı̧̧a neden olduğunu göstermiştir. UV ışımanın etkisiyle tüm numunelerin mekanik özelliklerinde bir azalma gözlenmiştir. Tüm numuneler için en hızlı azalma ilk 250 saatin sonunda tespit edilmiştir. Mekanik özelliklerdeki kayıp, şartlandırma testleri sonlandırılana kadar devam etmiştir. 1000 saatlik şartlandırmanın sonunda referans ipliklerin kopma mukavemeti $\% 79$, kopma uzaması $\% 90$ oranında azalmıştır. Bu durum katkılı ipliklerde, $\% 42$ kopma mukavemeti ve $\% 65$ kopma uzaması kaybı olarak gözlenmiştir.

Kumaş numunelerinde de benzer durum tespit edilmiştir. 1000 saatin sonunda referans kumaşların kopma kuvveti değerlerinde $\% 86$, katkı1ı numunelerin kopma kuvvetlerinde $\% 70$ oranında bir azalma tespit edilmiştir. Kopma uzaması değerlerinde ise test sonunda referans kumaşta yaklaşı \% 86 , katkılı kumaşta yaklaşı \% 71 ’lik bir kayıp meydana gelmiş̧ir.

Şartlandırma testleri sonunda katkılı kumaş numunelerinin referans numunelere oranla yaklaşık \%25 daha az sararma gösterdiği gözlenmiştir.

Sonuçta HPT türevi bir katkı maddesi olan Tinuvin 1577 ED’nin PET iplik ve kumaşlarının UV 1şımaya karşı dirençlerini arttırmada etkili oldukları tespit edilmiştir. Bu katkı maddesi kullanılarak üretilen PET tekstil mamullerinin katkısızlara oranla daha uzun süre açık hava koşullarında özelliklerini koruyarak kullanılabilecekleri söylenebilir.

\section{Teşekkür}

Bu çalışma, yazarlardan Nimet Doğmuş Yılmaz'ın yüksek lisans tezinden hazırlanmıştır.

\section{Kaynakça}

Anonim, (2012). https://adhesives.specialchem.com/selection-guide/uv-light-stabilizers-state-of-the-art/ultraviolet-absorbers (Erişim tarihi:18.05.2017).

Anonim, (2015). Weathering Testing Guidebook. http://www.strenometer.dk/Files/Downloads/Guidebook.pdf (Erişim tarihi:24.12.2018).

Gugumus, F. (2002). Posibilities and limits of synergism with light stabilizers in polyolefins 2. UV absorbers in polyolefins. Polymer Degradation and Stability, 75(2), 309-320.

McCusker, M. (1999a). A UVA-HALS Primer: Everything You've Ever Wanted to Know About Light Stabilizers Part 1, Metal Finishings, 97(5), 51-53.

McCusker, M. (1999b). A UVA-HALS Primer: Everything You've Ever Wanted to Know About Light Stabilizers Part 2. Metal Finishings, 97(6), 83-86.

Schaller, C., Rogez, D., \&Braig, A. (2009). Hindered amin light stabilizers in pigmented coatings. Journal of Coating Technologies and Research, 6(1), 81-88.

Wypych, G. (2013). Handbook of Material Weathering. Toronto: Chemteg Publishing. 